\title{
PENGEMBANGAN PERANGKAT PEMBELAJARAN FISIKA MODEL BERBASIS MASALAH PADA MATERI ELASTISITAS UNTUK MENINGKATKAN KEMAMPUAN GENERIK SAINS PESERTA DIDIK
}

\author{
Via Monica Devi'1), Susilawati ${ }^{1)}$, I Wayan Gunada ${ }^{1)}$ \\ 1)Program Studi Pendidikan Fisika, FKIP, Universitas Mataram, Mataram, NTB, Indonesia \\ Corresponding author : Via Monica Devi \\ E-mail : via.m.devi@gmail.com
}

Diterima 07 Januari 2021, Direvisi 23 Maret 2021, Disetujui 24Maret 2021

\begin{abstract}
ABSTRAK
Pandemi Covid-19 telah memberikan dampak yang signifikan dalam dunia pendidikan. Dampak pandemi Covid-19 ini menuntut peserta didik maupun pendidik untuk dapat beradaptasi dalam melakukan pembelajaran jarak jauh. Pada prosesnya, pembelajaran jarak jauh masih dianggap kurang efisien dalam pelaksanaannya terutama pada proses transfer materi ajar. Akibatnya banyak peserta didik yang mengabaikan pembelajaran. Salah satu upaya mengatasi permasalahan tersebut adalah dengan dilakukan pemilihan model dan metode pembelajaran yang sesuai dengan kondisi saat ini, sehingga perangkat pembelajaran yang digunakan perlu dilakukan pengembangan sebelum digunakan. Penelitian ini menggunakan jenis penelitian Research and Development (R\&D) dengan model 4D yang terdiri dari empat tahapan yaitu Define, Design, Develop, dan Disseminate. Perangkat yang dikembangkan pada penelitian ini adalah silabus, RPP, LKPD, dan instrumen tes kemampuan generik sains. Kevalidan perangkat yang dikembangkan diperoleh berdasarkan validitas dari enam validator yaitu tiga validator ahli dan tiga validator praktisi, kemudian kevalidan perangkat dianalisis dengan menggunakan skala Likert. Selanjutnya, keefisienan perangkat ditentukan dari respon peserta didik dan respon guru. Berdasarkan hasil penelitian yang telah dilakukan, diperoleh nilai rata-rata validitas diatas 3.26 dengan kategori sangat baik. Pembelajaran daring yang dilakukan berdasarkan respon peserta didik menunjukkan bahwa peserta didik kurang puas sehingga pembelajaran daring yang dilakukan kurang efisien hal tersebut dikarenakan adanya beberapa kendala salah satunya adalah keterbatasan kuota internet peserta didik. Maka dapat disimpulkan perangkat pembelajaran fisika model berbasis masalah pada materi elastisitas valid tetapi kurang efisien untuk digunakan dalam pembelajaran daring.
\end{abstract}

Kata kunci: perangkat pembelajaran; pembelajaran berbasis masalah; generik sains.

\begin{abstract}
The Covid-19 pandemic has had a significant impact on the world of education. The impact of the Covid19 pandemic requires students and educators to be able to adapt in doing distance learning. In the process, distance learning is still considered inefficient in its implementation, especially in the process of transferring teaching materials. As a result, many students ignore learning. One of the efforts to overcome this problem is by selecting a learning model and method that is in accordance with the current conditions, so that the learning tools used need to be developed before use. This study uses a Research and Development (R\&D) type of research with a 4D model consisting of four stages, namely Define, Design, Develop, and Disseminate. The tools developed in this study were the syllabus, lesson plans, student worksheet, and generic science proficiency test instruments. The validity of the developed device was obtained based on the validity of six validators, namely three expert validators and three practitioner validators, then the validity of the devices was analyzed using a Likert scale. Furthermore, the efficiency of the device is determined from the responses of students and teacher responses. Based on the results of the research that has been done, the average value of validity is above 3.26 with the very good category. Online learning that is carried out based on the responses of students shows that students are not satisfied so that online learning is not efficient because there are several obstacles, one of which is the limited internet quota of students. So it can be concluded that problem-based model physics learning tools on elasticity material are valid but less efficient for use in online learning.
\end{abstract}

Keywords: learning tools; problem-based learning; generic science. 


\section{PENDAHULUAN}

Dampak pandemi Covd-19 sangat berpengaruh terhadap dunia pendidikan. Dampak tersebut menuntut seorang pendidik untuk beradaptasi dengan strategi pembelajaran baru, dimana sebelumnya pembelajaran dilakukan secara tatap muka beralih dengan menggunakan media online atau media e-learning. Peralihan strategi mengajar tersebut, tentunya tetap menuntut pendidik untuk tetap memperhatikan aspek kurikulum yang berlaku, yakni kurikulum 2013 (K13). Pada K13, peserta didik dituntut untuk memiliki kemampuan berpikir tingkat tinggi. Salah satu yang meliputi kemampuan berpikir tingkat tinggi adalah kemampuan generik sains. Kemampuan generik sains merupakan kemampuan dasar yang dapat dikembangkan melalui pembelajaran sains (Agustin, 2014). Kemampuan generik sains berdasarkan pernyataan tersebut perlu dilakukan pengembangan. Tujuan dari pengembangan kemampuan generik sains sendiri adalah agar pengetahuan dan kemampuan yang diperoleh dari hasil belajar dalam proses belajar mengajar dapat diaplikasikan dalam kehidupan nyata dan menjawab tantangan zaman yang semakin cepat perkembangannya terutama dalam hal sains dan teknologi (Kusdiwelirawan et al., 2015). Sehingga, untuk menunjang hal tersebut perlu dilakukan pemilihan model pembelajaran yang tepat. Salah satu model pembelajaran yang dapat digunakan adalah model pembelajaran berbasis masalah (PBM).

Model PBM sendiri merupakan model pembelajaran yang menantang peserta didik untuk "belajar dalam belajar", bekerja secara kelompok untuk mencari solusi dari permasalahan (Kusdiwelirawan et al., 2015). Kelebihan model PBM yang dikutip dari (Wulandari \& Surjono, 2013) antara lain bahwa model PBM dapat menantang kemampuan peserta didik dalam pembelajaran, selain itu model PBM juga dapat meningkatkan keaktifan peserta didik, dan merangsang peserta didik untuk belajar secara kontinu. Adapun sintaks dari model PBM yang digunakan pada penelitian ini adalah mengorientasi peserta didik pada masalah, mengorganisasi peserta didik, membimbing penyelidikan individu maupun kelompok, mengembangkan dan menyajikan hasil karya, hingga menganalisis serta mengevaluasi proses pemecahan masalah. Sehingga model PBM ini dianggap cocok untuk menunjang kemampuan generik sains peserta didik. Hal tersebut sesuai dengan hasil peneltian yang dilakukan oleh Yahya \& Fitriyanto (2016), dimana model PBM terbukti dapat meningkatkan kemampuan generik sains peserta didik.
Berdasarkan hasil observasi yang peneliti lakukan di MAN 1 Mataram melalui wawancara, bahwa guru jarang menggunakan model pembelajaran tertentu dalam melakukan pembelajaran dan cenderung menggunakan metode ceramah. Hal tersebut menyebabkan sebagian peserta didik merasa bosan dengan pembelajaran yang dilakukan, sehingga peserta didik kurang bisa menguasai materi pembelajaran salah satunya pada materi elastisitas. Permasalahan yang ditemukan pada peserta didik untuk materi elastisitas adalah banyaknya miskonsepsi terhadap konsep-konsep sederhana pada materi elastisitas yang menyebabkan peserta didik kesulitan dalam memahami dan mengaplikasian konsep tersebut dalam permasalahan yang lebih kompleks. Fenomena yang demikian menjadi salah satu faktor rendahnya tingkat kemampuan generik sains peserta didik. Selain itu pembelajaran yang dilakukan selama pandemi berlangsung, juga cenderung hanya dilakukan dalam bentuk pemberian tugas harian tanpa dilakukan penjelasan materi pembelajaran. Oleh karena itu, peneliti berupaya untuk melakukan pengembangan perangkat pembelajaran fisika model berbasis masalah untuk meningkatkan kemampuan generik sains peserta didik pada materi elastisitas. Perangkat pembelajaran yang dimaksud adalah silabus, RPP, LKPD, dan soal kemampuan generik sains. Adapun sebelumnya, penelitian yang dilakukan oleh Istianah et al. (2015) telah membuktikan bahwa pengembangan perangkat pembelajaran berbasis masalah mampu meningkatkan kemampuan generik sains peserta didik.

\section{METODE PENELITIAN Jenis Penelitian}

Jenis penelitian yang digunakan pada penelitian ini adalah penelitian dan pengembangan (Research and Development) dengan menggunakan model pengembangan 4D yang meliputi tahap pendefinisian (Define), perancangan (Design), pengembangan (Develop), dan penyebaran (Disseminate) (Sugiyono, 2016).

\section{Prosedur Penelitian}

Tahap pendefinisian (Define), dilakukan analisis perangkat pembelajaran guna menentukan tujuan pembelajaran sesuai dengan KD dan IPK pada materi elastisitas. Pada tahapan ini juga dilakukan analisis perangkat pembelajaran yang digunakan oleh guru di sekolah yang kemudian peneliti kembangkan dan disesuaikan dengan model PBM serta kebutuhan dalam melakukan pembelajaran daring. 
Tahap perancangan (Design) adalah tahapan lanjutan dari pendefinisian (Define). Pada tahap perancangan ini, dilakukan pembuatan draft dari produk yang dikembangkan dimana dalam hal ini produk yang dimaksud adalah perangkat pembelajaran.

Selanjutnya tahap pengembangan (Develop) dimana pada tahapan ini, draft dari produk yang dibuat kemudian dilakukan validasi oleh pakar. Validasi pakar ini terdiri dari enam validator yang diantaranya adalah tiga validator ahli dan tiga validator praktisi. Validator ahli yang dimaksudkan adalah Dosen Program Studi Pendidikan Fisika, Universitas Mataram. Sedangkan untuk validator praktisi merupakan guru yang mata pelajaran fisika yang telah memiliki pengalaman mengajar lebih dari 5 tahun. Proses validasi sendiri dimulai dengan meminta kepada validator untuk memberikan nilai sesuai dengan kolom dan baris pada aspek yang dinilai (Harahap et al., 2019). Adapun untuk LKPD dan soal kemampuan generik sains juga dilakukan penilaian oleh peserta didik yang telah mendapatkan pembelajaran pada materi elastisitas.

Untuk tahapan penyebaran (Disseminate) pada penelitian ini tidak dilakukan, hal tersebut dikarenakan keterbatasan kondisi dampak dari Pandemi Covid-19 yang tidak memungkinkan untuk peneliti melakukan uji coba skala luas.

\section{Instrumen Penelitian}

Instrumen penelitian Instrumen penelitian adalah seperangkat alat yang dimaksudkan untuk mengukur ketercapaian kompetensi pembelajaran yang telah direncanakan sebelumnya (Sahidu, 2016). Instrumen penelitian yang dimaksudkan pada penelitian ini berupa lembar wawancara, lembar validasi ahli, angket respon peserta didik, dan butir soal kemampuan generik sanis. Lembar wawancara digunakan untuk pedoman awal dalam mengetahui aktivitas dan kendala-kendala saat pembelajaran. Selanjutnya untuk lembar validasi ahli, digunakan untuk mengetahui validitas (kelayakan) dari pengembangan perangkat pembelajaran yang akan digunakan. Untuk angket respon peserta didik, diberikan pada pertemuan terakhir dari pembelajaran untuk materi yang bersangkutan guna mengetahui respon peserta didik terhadap kegiatan pembelajaran dan perangkat pembelajaran yang digunakan (Sudiarman et al., 2015). Serta instrumen tes soal kemampuan generik sains digunakan untuk mengetahui peningkatan kemampuan generik sains peserta didik.

\section{Teknik Pengumpulan Data}

Teknik pengumpulan data yang digunakan pada penelitian pengembangan ini untuk validitas perangkat pembelajaran adalah dengan menggunakan skala Likert. Perhitungan validitas perangkat bertujuan untuk mengetahui kevalidan atau kelayakan perangkat yang dikembangkan. Kelayakan dari perangkat tersebut kemudian dikategorikan menjadi beberapa tingkat kelayakan yang ditunjukkan pada Tabel 1 berikut:

Tabel 1: Tingkat Kelayakan Instrumen

\begin{tabular}{lll}
\hline Skor & Rerata Skor & Klasifikasi \\
\hline 4 & $3,26-4,00$ & Sangat Baik \\
3 & $2,51-3,25$ & Baik \\
2 & $1,76-2,50$ & Kurang Baik \\
1 & $1,01-1,75$ & Tidak Baik \\
\hline
\end{tabular}

(Suyanto \& Sartinem, 2009)

Skor dari konversi kelayakan tersebut sebelumnya dicari dengan menggunakan persamaan:

$$
\text { skor }=\frac{\sum \text { penilaian yang didapat }}{\sum \text { penilaian maksimal }} \times 4
$$

Keefisienan perangkat pembelajaran ditentukan dengan menggunakan angket respon. Angket respon ini nantinya diisi oleh peserta didik setelah rangkaian pembelajaran dilakukan. Pengisian angket respon oleh peserta didik dilakukan dengan penyebaran link google form. Hasil dari tanggapan atau respon peserta didik tersebut kemudian dilakukan tabulasi guna menentukan keefisienan dari penerapan perangkat pembelajaran model berbasis masalah yang dibuat oleh peneliti.

\section{HASIL DAN PEMBAHASAN \\ Tahap Pendefinisian (Define)}

Tahap pendefinisian (Define) merupakan tahapan awal dalam melakukan penelitian pengembangan untuk model pengembangan 4D. Pada tahapan ini dilakukan analisis awal berupa wawancara secara langsung dengan guru pelajaran fisika di MAN 1 Mataram guna mendapatkan gambaran pembelajaran di kelas. Analisis ini dilakukan sebelum dan saat pandemi berlangsung. Dimana pada saat pembelajaran tatap muka, peserta didik terbiasa mengikuti penjalasan guru mengenai materi pembelajaran yang disampaikan dengan metode ceramah, hal tersebut membuat sebagian peserta didik merasa bosan karena kegiatan peserta didik cenderung pasif. Sementara itu, ketika pembelajaran daring dilakukan ada beberapa kesulitan yang dialami oleh guru maupun peserta didik yang dimana kondisi tersebut mengharuskan guru dan peserta didik untuk belajar menggunakan 
media online atau media e-learning dalam melakukan pembelajaran. Permasalahan lainnya dalam melakukan pembelajaran daring adalah keterbatasan kuota internet yang dimiliki oleh peserta didik, sehingga menyebabkan sebagian peserta didik tidak dapat hadir disetiap pertemuan selain itu, penyampaian materi kepada peserta didik juga menjadi kurang optimal.

Berdasarkan analisis awal tersebut, kemudian dilakukan analisis tugas yang disesuaikan dengan KD dan IPK pada materi elastisitas. Selanjutnya dilakukan pula analisis konsep, serta perumusan tujuan pembelajaran. Langkah-langkah tersebut sesuai dengan tujuan dari tahapan pendefinisian (define) menurut Yusuf et al. (2015), bahwa tujuan tahap pendefinisian adalah untuk menetapkan serta mendefinisikan syarat-syarat pembelajaran yang meliputi analisis awal hingga spesifikasi tujuan pembelajaran.

\section{Tahap Perancangan (Design)}

Tahap perancangan merupakan tahapan lanjutan setalah dilakukan tahap pendefinisian. Pada dasarnya, tahap perancangan ini digunakan untuk melakukan perencanaan produk awal yang dikembangkan dalam hal ini merancang perangkat pembelajaran yang berorientasi pada model berbasis masalah (Gunada et al., 2017). Kemudian dari tahap perancangan ini nantinya akan diperoleh draft awal berupa perangkat pembelajaran serta instrumen pengumpulan data. Pada perangkat pembelajaran, untuk silabus penyusunan rancangan dimodifikasi dari silabus yang sudah ada dan kemudian disesuaikan dengan pemilihan model pembelajaran yang digunakan, dalam hal ini adalah model PBM. Untuk RPP perumusan $\mathrm{KD}$ dan $\mathrm{KI}$ disesuaikan dengan silabus yang telah dikembangkan sebelumnya, dimana standar isi yang digunakan sesuai dengan Permendikbud No.21 Tahun 2016. Sedangkan untuk LKPD disesuaikan dengan model PBM, sehingga pada LKPD perlu adanya kolom rumusan masalah dan hipotesis, dan untuk tujuan dari LKPD yang digunakan adalah turunan dari tujuan pada RPP. Selanjutnya untuk soal kemampuan generik sains, yang dimana perancangan susunan soal dirancang dalam bentuk soal uraian yang setiap soalnya mencakup tujuan serta indikator kemampuan generik sains. Sementara untuk instrumen pengumpulan data, dilakukan penyusunan lembar validasi serta angket respon peserta didik.

\section{Tahap Pengembangan (Develop)}

Tahap pengembangan (Develop) merupakan tahapan untuk memperoleh produk pengembangan. Produk pengembangan ini didapatkan melalui uji validitas dan uji coba terbatas. Uji validitas dilakukan oleh tiga validasi ahli dan tiga validasi praktisi, sedangkan untuk uji coba terbatas dilakukan di MAN 1 Mataram pada kelas XI MIA 3. Perolehan hasl uji validitas oleh ahli dan praktisi tersebut selanjutnya dianalisis dengan menggunakan skala likert, sehingga diperoleh rata-rata sebagai berikut.

Tabel 2: Validitas Perangkat oleh Ahli

\begin{tabular}{ccc}
\hline Perangkat & Nilai Rata-Rata & Kategori \\
\hline Silabus & 3.42 & Sangat Baik \\
RPP & 3.27 & Sangat Baik \\
LKPD & 3.30 & Sangat Baik \\
Soal KGS & 3.19 & Baik \\
\hline
\end{tabular}

Tabel 3: Validitas Perangkat oleh Praktisi

\begin{tabular}{ccc}
\hline Perangkat & Nilai Rata-Rata & Kategori \\
\hline Silabus & 3.79 & Sangat Baik \\
RPP & 3.75 & Sangat Baik \\
LKPD & 3.70 & Sangat Baik \\
Soal KGS & 3.74 & Sangat Baik \\
\hline
\end{tabular}

Berdasarkan hasil validitas pada Tabel 2 dan Tabel 3, dapat dikatakan bahwa rata-rata validitas perangkat pembelajaran yang dibuat masuk ke dalam kategori sangat baik. Selain itu, perangkat pembelajaran untuk LKPD dan soal kemampuan generik sains juga dilakukan penilaian oleh peserta didik yang telah mendapatkan materi elastisitas, dalam hal ini peneliti memilih kelas XI MIA 1 untuk meberikan penilaian. Berikut merupakan hasil penilaian perangkat oleh peserta didik kelas XI MIA 1 yang berjumlah 26 orang.

Tabel 4: Penilaian Perangkat oleh XI MIA 1

\begin{tabular}{ccc}
\hline $\begin{array}{c}\text { Perangk } \\
\text { at }\end{array}$ & $\begin{array}{c}\text { Nilai Rata- } \\
\text { Rata }\end{array}$ & Kategori \\
\hline LKPD & 3.26 & Sangat Baik \\
Soal KGS & 3.46 & Sangat Baik \\
\hline
\end{tabular}

Tabel 4 di atas menunjukkan bahwa perangkat LKPD dan soal kemampuan generik sains yang dibuat masuk ke dalam kategori sangat baik. Artinya, perangkat pembelajaran layak digunakan. Hal tersebut sesuai dengan hasil penelitian yang dilakukan oleh Susdarwati et al. (2016) dan Jiniarti et al. (2019) yang menyatakan bahwa perangkat pembelajaran fisika berbasis masalah yang telah dikembangkan dengan kategori layak dapat digunakan dalam uji coba. Selain mendapatkan hasil validitas dari tiap-tiap perangkat pembelajaran, peneliti juga mendapatkan beberapa saran untuk perbaikan perangkat pembelajaran. Saran tersebut kemudian peneliti jadikan sebagai bentuk revisi awal dari produk yang dibuat. Revisi tersebut juga bertujuan agar produk yang dikembangkan menjadi lebih baik. Beberapa revisi yang 
diberikan antara lain seperti perbaikan redaksi kalimat, penyesuaian penulisan EYD pada perangkat pembelajaran, memperjelas gambar pada perangkat pembelajaran khusunya pada LKPD dan soal KGS. Perbaikan yang diberikan berupa saran tersebut kemudian dilakukan revisi. Setelah dilakukan revisi, maka produk selanjutnya dapat digunakan untuk melakukan uji coba terbatas.

Uji coba terbatas dilakukan pada kelas XI MIA 3 yang berjumlah 28 orang. Tujuan dilakukan uji coba terbatas adalah untuk mengetahui keefisienan penerapan perangkat pembelajaran yang dibuat oleh peneliti. Pembelajaran yang dilakukan dalam uji coba terbatas dengan mengunakan media online berupa whatsapp dan media e-learning (google classroom). Pada pelaksanaannya, tidak bisa dipungkiri bahwa pembelajaran daring memiliki banyak keterbatasan. Salah satunya adalah ketersediaan waktu pembelajaran daring jauh lebih singkat jika dibandingkan dengan pembelajaran tatap muka. Selain itu, kendala lainnya adalah keterbatasan kuota internet yang mana kuota internet manjadi sesuatu kebutuhan utama yang menunjuang keterlaksanaan pembelajaran daring. Meskipun demikian, pembelajaran daring yang dilakukan pada kelas XI MIA 3 mendapatkan respon positif dari guru. Tetapi, berdasarkan angket respon peserta didik didapatkan berbagai macam tanggapan baik itu tanggapan yang bersifat positif maupun tanggapan negatif. Tanggapan-tanggapan tersebut kemudian dilakukan tabulasi, sehingga diperoleh data sebagai berikut.

Tabel 5: Tabulasi Tanggapan Peserta Didik

\begin{tabular}{ccc}
\multicolumn{3}{c}{ Kelas XI MIA 3 } \\
\hline \multirow{3}{*}{ Tanggapan } & $\begin{array}{c}\text { Jumlah } \\
\text { Peserta } \\
\text { Didik }\end{array}$ & Persentase \\
&
\end{tabular}

Positif (Menyukai
pembelajaran
dengan
model/metode yang
digunakan, mudah
dalam mengikuti
dan memahami
materi
pembelajaran)
Negatif (Tidak
menyukai
pembelajaran
daring, mengalami
kesulitan dalam
mengikuti dan
memahami materi
pembelajaran)

\begin{tabular}{lcc}
\hline Tanggapan & $\begin{array}{c}\text { Jumlah } \\
\text { Peserta } \\
\text { Didik }\end{array}$ & Persentase \\
\hline $\begin{array}{l}\text { Tidak ada } \\
\text { tanggapan }\end{array}$ & 14 & $50.00 \%$ \\
\hline
\end{tabular}

Berdasarkan Tabel 5, dapat dilihat bahwa dari 28 peserta didik hanya 6 peserta didik yang memberikan respon positif, kemudian 8 peserta didik memberikan tanggapan negatif, dan sisanya sebanyak 14 orang memilih untuk tidak memberikan tanggapan. Sehingga berdasarkan angket respon peserta didik, penerapan perangkat pembelajaran model berbasis masalah kurang efisien untuk digunakan dalam pembalajran daring. Hal tersebut juga dikarenakan keterbatasan kuota internet yang menyebabkan sebagian peserta didik tidak dapat mengikuti pembelajaran setiap pertemuan. Selain itu keterbatasan waktu pembelajaran yang tersedia lebih singkat dibandingkan kegiatan pembelajaran normal hal tersebut menyebabkan peserta didik kurang leluasa jika ingin bertanya. Sejalan dengan pendapat (Wulandari \& Surjono, 2013) bahwa penerapan model PBM tidak jarang memerlukan waktu yang lebih banyak.

\section{Tahap Penyebaran (Disseminate)}

Tujuan dari tahapan penyebaran (Disseminate) menurut Kurniawan \& Dewi (2017) adalah untuk melakukan tes validasi terhadap perangkat pembelajaran yang telah diuji cobakan dan direvisi, kemudian disebarkan ke lapangan (uji coba skala luas). Tetapi karena keterbatasan kondisi pada penelitian kali ini maka pada tahapan penyebaran (Disseminate) tidak dilakukan.

\section{SIMPULAN DAN SARAN}

Pengembangan

perangkat pembelajaran fisika model berbasis masalah pada materi elastisitas dikatakan valid dengan kategori keseluruhann perangkat pembelajaran adalah sangat baik, namun penerapan dari perangkat pembelajaran berdasarkan tabulasi tanggapan peserta didik munjukkan penerapan dari perangkat pembelajaran masih kurang efisien dikarenakan beberapa keterbatasan. Berdasarkan keterbatasan-keterbatasan tersebut, maka saran dalam melakukan penelitian pengembangan khususnya dalam pembelajaran daring yaitu dengan menggunakan media online seperti zoom, google meet, atau media e-learning lainnya, serta memberikan keringanan tenggat waktu bagi peserta didik dalam mengumpulkan tugas. 


\section{DAFTAR RUJUKAN}

Agustin, R. R. (2014). Pengembangan Keterampilan Generik Sains Melalui Penggunaan Multimedia Interaktif. Jurnal Pengajaran Matematika Dan IImu Pengetahuan Alam, 18(2), 253. https://doi.org/10.18269/jpmipa.v18i2.58

Gunada, I. W., Sahidu, H., \& Sutrio, S. (2017). Pengembangan Perangkat Pembelajaran Fisika Berbasis Masalah untuk Meningkatkan Hasil Belajar dan Sikap Ilmiah Mahasiswa. Jurnal Pendidikan Fisika Dan Teknologi, 1(1), 38. https://doi.org/10.29303/jpft.v1i1.233

Harahap, R. S. I., Derlina, \& Abidin, Z. (2019). Pengembangan Perangkat Pembelajaran Fisika dengan Model Pembelajaran Kooperatif Berbasis Budaya Batak. 8(1), 47-56.

Istianah, R., I.S, M.S, K., \& Widodo, A. T. (2015). Pengembangan Perangkat Pembelajaran Berbasis Masalah (Problem Based Learning)Untuk Meningkatkan Keterampilan Generik Sains Siswa Sma. Journal of Innovative Science Education, 4(1), 1-10.

Jiniarti, B. E., Harjono, A., \& Makhrus, M. (2019). Pengembangan Perangkat Model Pembelajaran Berbasis Masalah Berbantuan Virtual Eksperimen untuk Meningkatkan Penguasaan Konsep Peserta Didik Pada Materi Alat-Alat Optik. Sustainability (Switzerland), 14(2), 25-30.

Kurniawan, D., \& Dewi, S. V. (2017). Pengembangan Perangkat Pembelajaran Dengan Media Screencast- O-Matic Mata Kuliah Kalkulus 2 Menggunakan Model 4D Thiagarajan. Jurnal Siliwangi, 3(1), 214-219.

Kusdiwelirawan, A., Hartini, T. I., \& Najihah, A. R. (2015). Perbandingan Peningkatan Keterampilan Generik Sains Antara Model Inquiry Based Learning dengan Model Problem Based Learning. Jurnal Fisika Dan Pendidikan Fisika, 1(2).

Sahidu, H. (2016). Evaluasi Pembelajaran Fisika. Agra Puji Press.

Sudiarman, Soegimin, W., \& Susantini, E. (2015). Pengembangan Perangkat Pembelajaran Fisika Berbasis Inkuiri Terbimbing untuk Melatihkan Keterampilan Proses Sains dan Meningkatkan Hasil Belajar Topik Suhu dan Perubahannya. Pendidikan Sains Pascasarjana Universitas Negeri Surabaya, 4(2), 658-671.

Sugiyono. (2016). Metode Penelitian Pengembangan. Alfabeta.

Susdarwati, S., Sarwanto, S., \& Cari, C. (2016). Pengembangan Perangkat Pembelajaran
Fisika Berbasis Problem Based Learning (Pbl) Pada Materi Hukum Newton Dan Penerapannya Kelas X Sman 2 Mejayan. INKUIRI: Jurnal Pendidikan IPA, 5(3), 1. https://doi.org/10.20961/inkuiri.v5i3.9434

Suyanto, E., \& Sartinem. (2009). Pengembangan Contoh Lembar Kerja Fisika Peserta Didik dengan Latar Penuntasan Bekal Awal Ajar Tugas Studi Pustaka dan Kemampuan Proses untuk SMA Negeri 3 Bandar Lampungtle. Prosiding Seminar Nasional Pendidikan Tahun 2009.

Wulandari, B., \& Surjono, H. D. (2013). Pengaruh problem-based learning terhadap hasil belajar ditinjau dari motivasi belajar PLC di SMK. Jurnal Pendidikan Vokasi, 3(2), 178-191. https://doi.org/10.21831/jpv.v3i2.1600

Yahya, F., \& Fitriyanto, S. (2016). Pengaruh Model Pembelajaran Berbasis Masalah Berbantuan Simulasi Interaktif Terhadap Keterampilan Generik Sains Siswa SMA Pada Materi Elastisitas. Jurnal Pendidikan Fisika Dan Teknologi, II(3), 136-141.

Yusuf, I., Widyaningsih, S. W., \& Purwati. (2015). Pengembangan perangkat pembelajaran Fisika Modern berbasis media laboratorium virtual berdasarkan paradigma pembelajaran abad 21 dan Kurikulum 2013. Pancaran Pendidikan, 4(2), 189-200. 